\title{
Rancang Bangun Penampung Sampah Laut Portable (PSP) Dan Uji Solar Panel untuk Mengurangi Sampah Laut
}

\author{
Amanda T Siboro*, Feby Angelin Garizi Siahaan*, Sarnaen Simanjuntak", Muhammad \\ Zainuddin Lubis* \\ * Politeknik Negeri Batam \\ Jurusan Teknik Informatika, Program Studi Teknik Geomatika \\ Batam Center, Jl. Ahmad Yani, Kepulauan Riau 29461, Indonesia \\ \# Politeknik Negeri Batam \\ Jurusan Teknik Mekatronika \\ Batam Center, Jl. Ahmad Yani, Kepulauan Riau 29461, Indonesia \\ E-mail: amandasiboro@gmail.com, zainuddinlubis@ polibatam.ac.id
}

\begin{abstract}
Abstrak
Sampah laut adalah sampah hasil pembuangan yang dihasilkan oleh manusia yang terbuang ke lingkungan pesisir dan laut. Keberagaman aktivitas manusia yang tersebar dimana saja dapat menjadi sumber sampah. Sumber ini dapat berlokasi di laut, sepanjang pesisir, maupun daerah pedalaman. Sampah - sampah ini berpindah dari satu tempat ke tempat lain dalam jarak yang jauh dan dapat memasuki habitat laut. Akumulasi dari sampah laut, tentunya dapat mempengaruhi habitat makhluk hidup, fungsi ekologikal organisme, dan juga dapat menimbulkan masalah kesehatan. Tujuan dari penelitian ini adalah untuk menguji kinerja prototipe penampung sampah laut portable (PSP) dalam mengurangi jumlah sampah laut. Metode pengujian yang digunakan yaitu menghitung volume sampah laut yang diperoleh pada daerah uji coba yaitu Pantai Biru Sehati, Tanjung Piayu, mengidentifikasi ukuran dan jenis bahan sampah yang tertampung, mengukur luas cakupan area yang dapat dijangkau oleh prototipe, sekaligus dilakukan juga identifikasi parameter oseanografi yang ada pada daerah uji untuk melihat pengaruh parameter oseanografi terhadap kinerja prototipe. Dimana dari hasil pengujian, diketahui berat maksimum yang dapat ditampung oleh prototipe adalah $0.5-1 \mathrm{~kg}$, dengan kecepatan motor $2800 \mathrm{rpm}$, Parameter oseanografi yang teridentifikasi yaitu kecepatan arus $0.7 \mathrm{~m} / \mathrm{s}$. Hasil uji lapangan juga menunjukkan parameter oseanografi juga berpengaruh dalam keefektifan kinerja prototipe.
\end{abstract}

Kata kunci: Rancang bangun, sampah laut, penampung sampah laut portable, oseanografi

\begin{abstract}
Marine litter is waste created by human that has been discharged into the coastal or marine environment. Varied and widespread human activities can act as the source of marine litter. The sources may be located directly at sea, on the coast or inland. Litters can be transported over long distances and into marine habitat. Accumulation of marine litter can affects habitats, organism ecological function, and develops health problems. The objective of present study was to evaluate portable marine litter collector's performance for eliminating marine litter. The methods consist of some steps i.e. measuring collected marine litter amount in the tested area which took place at Pantai Biru Sehati, Tanjung Piayu; identifying the size and type of material of the collected marine litter; measuring the scope that can be reached by the prototype; along with identifying oceanographic parameter regarding its effects on prototype performance. The results showed that the maximum weight that can be held by the prototype was 0.5 - $1 \mathrm{~kg}$ of marine litter, $2800 \mathrm{rpm}$ of motor speed. Furthermore, the identified oceanographic parameters are speed current which was $0.7 \mathrm{~m} / \mathrm{s}$. The field test also indicates that the oceanographic parameter affects the prototype performance.
\end{abstract}

Keywords: Design, marine litter, portable marine litter collector, oceanography

\section{Pendahuluan}

Indonesia adalah negara yang memiliki iklim yaitu iklim tropis, yang mempunyai potensi yang besar untuk dijadikan sebagai sumber energi alternatif contohnya energi surya. Kepulauan Riau adalah daerah yang terdapat banyak pulau-pulau kecil yang 80 | Jurnal Integrasi | Vol.10 No.2, October 2018, 80-85 | e-ISSN: 2548-9828 
belum mendapat pasokan listrik maka dari itu perlu dilakukan penelitian sumber - sumber energi yang ada di sekitarnyarnya, yang menggunakan energi matahari sebagai pembangkit listrik tenaga matahari untuk pulau-pulau kecil yang ada di daerah Kepulauan Riau, Batam. Masalah lingkungan sangat linear sekali kaitannya dengan dunia kesehatan. Untuk mencapai kondisi masyarakat yang sehat diperlukan lingkungan yang baik pula.

Laut merupakan sumberdaya alam yang sangat penting sebagai penyeimbang bumi. Saat ini, terutama di daerah Batam, Kepulauan Riau, masih banyak sekali sampah yang ada di laut, hal ini sering terlihat ketika durut tertinggi dan pasang tertinggi terjadi. Hal ini sangat mendorong, pentingnya dilakukan penelitian yang melakukan perancangan alat penampung sampah secara portable. Sampah laut (Marine Debris) adalah bahan padat persisten, yang sengaja atau tidak sengaja dibuang dan sekitar laut, baik melalui daerah pesisir, perairan dangkal, dan perairan dalam [1]. Sampah adalah masalah besar, bukan hanya di Indonesia, tetapi hal ini terjadi pada seluruh dunia. [2] menunjukkan bahwa plastik dan jumlah sampah yang ada di laut yaitu pantai Afrika Selatan mengalami peningkatan selama 21 tahun (1984-2005).

Batam, Kepulauan Riau merupakan daerah kepulauan yang sangat kaya akan sinar matahari. Solar pane adalah alat yang tepat untuk menyimpan energy di daerah kepulauan terutama di kepulauan Riau. Energi surya yang diterima oleh alat solar panel dalam satu hari memiliki variasi mulai dari $0.55 \mathrm{kWh} / \mathrm{m}^{2}$ $\left(2 \mathrm{MJ} / \mathrm{m}^{2}\right)$ pada daerah dingin, hingga $5.55 \mathrm{kWh} / \mathrm{m}^{2}$ $\left(20 \mathrm{MJ} / \mathrm{m}^{2}\right)$ pada lingkungan di daerah tropis $[3,4]$. Penelitian ini menggunakan panel surya $150 \mathrm{wp}$, untuk pengontrolan digunakan Arduino. Tujuan penelitian ini adalah untuk mengetahui rancangan yang baik dalam pembuatan alat penampung sampah portable (PSP), melakukan uji fungsi pada alat, karakteristik tegangan (volt) terhadap waktu, Karakteristik daya (watt) dan waktu. Nilai kuat arus laut terhadap waktu, dan mengidentifikasi hubungan daya sedot pompa terhadap arus laut. Dalam penelitian ini, diharapkan dapat menghasilkan alat penampung sampah portable yang hemat energi dan tepat guna untuk masyarakat di pesisir.

\section{Metode Pelaksanaan}

\subsection{Diagram Alir Pelaksanaan}

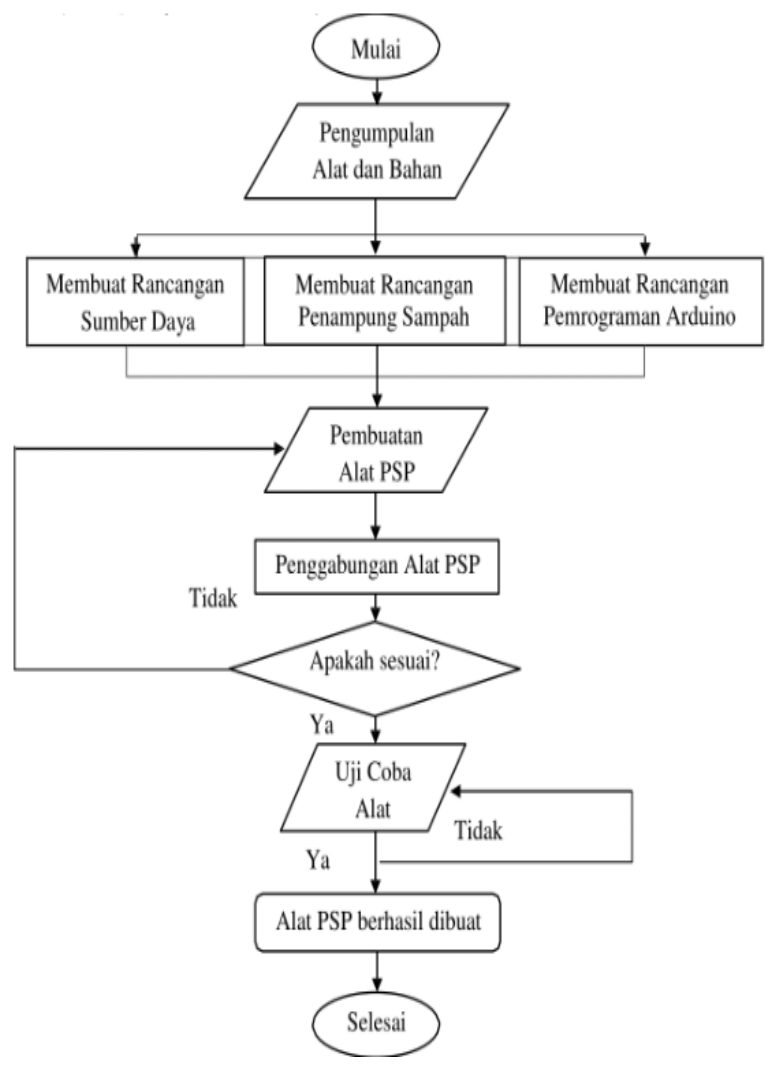

Gambar 1. Diagram Alir Pelaksanaan Program

\subsection{Pengujian Alat Secara Keseluruhan}

Alat dan bahan yang digunakan adalah berupa panel surya $150 \mathrm{wp}$, Arduino, Pompa, kerangka utama, alas, sensor float switch panel surya tanpa sistem tracker dan alat pengukuran arus laut

\subsection{Perancangan Struktural}

Desain terdiri dari bagian atas, tengah, dan bagian bawah. Bagian atas merupakan tempat panel surya yang ditopang oleh rangka plat besi yang akan diletakkan di pelantar suatu perairan sebagai dudukan alat tersebut. Terdapat instalasi pipa yang berfungsi menyedot sampah yang berada pada sekitar alat. Bagian tengah alat terdapat sensor float switch, yang 
berfungsi untuk mengetahui ketinggian air, ketika sensor dalam posisi berdiri, maka alat akan mati secara otomatis. Pada bagian bawah, terdapat pompa sebagai alat penyedot air, yang memiliki out dan in, yang disambungkan pada pipa menuju tempat penampungan sampah. Gambar perancangan struktural dapat dilihat pada Gambar 2.

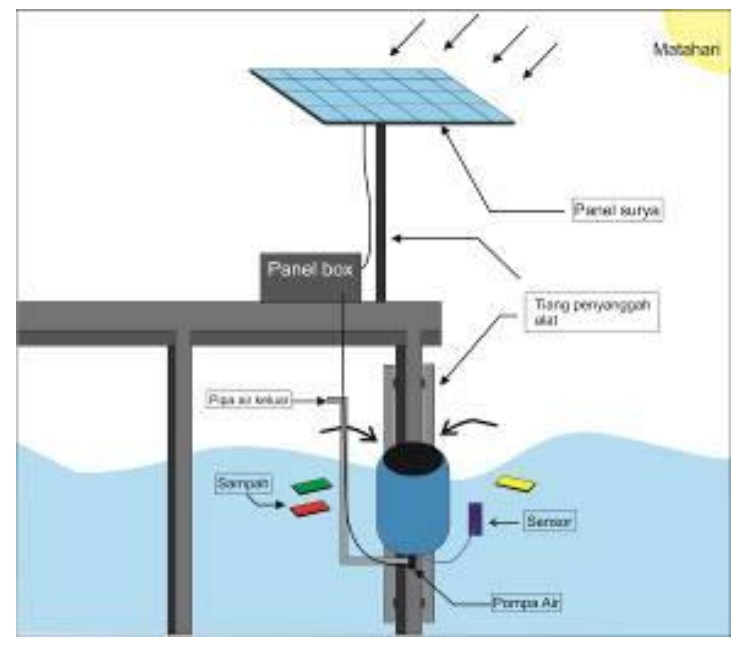

Gambar 2. Perancangan struktural (Desain) alat penampung sampah portable (PSP)

\subsection{Rancangan Fungsional}

Perancangan fungsional dari sistem alat penampung sampah portable (PSP), dapat dilihat pada Tabel 1 di bawah ini:

Tabel 1. Prinsip Kerja Alat

\begin{tabular}{|c|c|c|}
\hline No & Tindakan & Komponen Utama \\
\hline 1 & $\begin{array}{c}\text { Pembacaan dan } \\
\text { Pengendalian }\end{array}$ & Arduino \\
\hline 2 & Sensor & Float switch \\
\hline 3 & Daya sedot & $1.75 \mathrm{~L} / \mathrm{s}$ \\
\hline 4 & Energi & Solar Panel \\
\hline
\end{tabular}

\subsection{Pengujian Arduino dan Hidrolik Elektrik}

Pengujian Arduino dan hidrolik elektrik dapat disatukan karena hidrolik elektrik digunakan sebagai indikator kerja pada Arduino. Arduino akan diberikan program untuk menjalankan hidrolik elektrik, Jika hidrolik elektrik berhasil menyala dan melakukan proses mekanik dan menurunkan penampung sampah, maka berjalan sesuai program, maka hidrolik elektrik dinyatakan dalam kondisi baik. Begitu juga Arduino dinyatakan dalam kondisi baik karena dapat menerima dan membaca program.

\subsection{Pengujian Program}

Pengujian program dilakukan untuk mengidentifikasi apakah program berjalan dengan baik, yaitu menghubungkan program arduino dengan hidrolik elektrik.

\subsection{Pengujian Alat Secara Keseluruhan}

Pengujian alat secara keseluruhan yaitu melakukan pengujian pada alat yang telah di buat secara keseluruhan dan berhasil berjalan sesuai dengan keinginan. Sehingga akan diamati apakah pompa mampu melakukan proses sedot sesuai dengan yang di harapkan. Diagram alir cara kerja alat dapat dilihat pada Gambar 3. Gambar pengujian alat dapat dilihat pada Gambar 4.

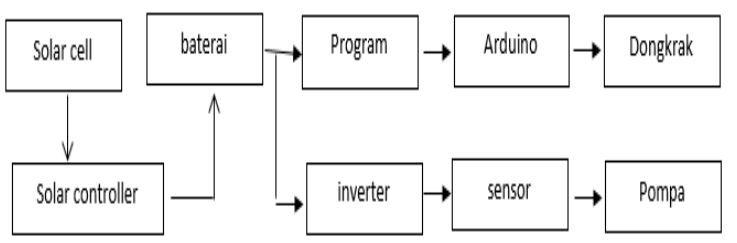

Gambar 3. Diagram Alir Cara Kerja Alat

Alat akan dioperasikan di daerah pinggiran laut, tepatnya pada rumah panggung dan dermaga. Alat lalu diletakkan pada tiang pondasi, sebelum alat dipasang, perlu dilakukan pengamatan tinggi pasang surut air laut. Alat akan diletakkan pada batas tinggi rata-rata pasang air laut. Setelah itu penyangga alat akan di pasang pada tiang pondasi. Kemudian kabel pompa akan dililitkan pada penyangga ke atas rumah ataupun dermaga. Solar cell akan menyerap energi, kemudian disalurkan ke baterai, lalu baterai sendiri disambungkan dengan solar controller, sehingga ketika baterai penuh, maka solar controller akan memutuskan energi. Kemudian baterai disambungkan dengan pompa melalui inverter. Setelah alat PSP bekerja, pompa secara otomatis akan membuat gaya tarikan layaknya seperti vakum yang akan menarik 
sampah dan air yang ada disekitar wadah. Kemudian setelah sampah yang berada di sekitar wadah mulai tertarik dan memasuki wadah, lalu air yang terdapat di dalam wadah akan dikeluarkan kembali setelah mengalami proses penyaringan yang dilakukan oleh penyaring sampah. Air dikeluarkan kembali ke laut melalui pipa keluar yang sudah dihubungkan dengan alat. Pompa pada alat ini memiliki sensor yang berfungsi untuk mengatur waktu kerja pompa, dimana ketika air laut surut, sensor tersebut akan mendeteksi tidak ada lagi air disekitar, maka pompa dengan sendirinya akan mati, begitu juga sebaliknya. Sedangkan pada bagian penyangga wadah dipasang hidrolik elektrik yang dihubungkan dengan arduino yang telah diprogram. Program dirancang untuk mengatur waktu yang dibutuhkan hidrolik elektrik pada saat proses naik dan turun. Hal ini berguna dalam memberi jeda waktu pada pompa untuk mengosongkan air yang ada pada wadah penampung sampah, sehingga dapat mencegah keluarnya kembali sampah ke laut.

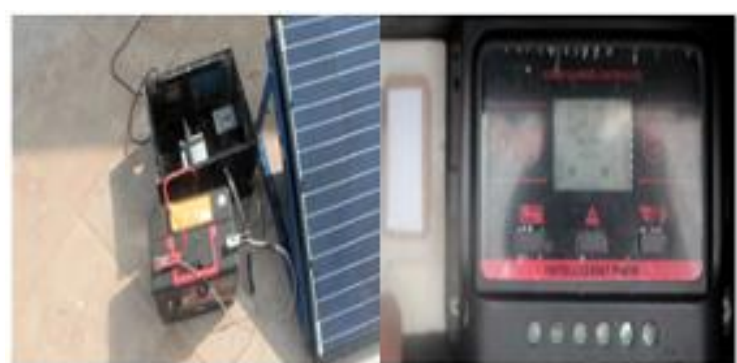

(a)

(b)

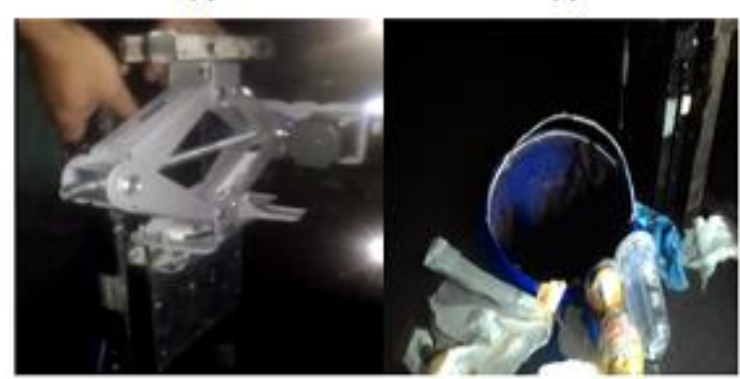

(c)

(d)

Gambar 4. Pengujian Alat

Untuk pengujian alat dapat dilihat pada Gambar 4, dimana kegiatan yang dilakukan pada pengujian alat ini yaitu menginstalasi seluruh komponen elektrikal yang terdiri dari panel surya, solar controller, inverter, Arduino, hidrolik elektrik dan mesin pompa, dan memastikan seluruh komponen berjalan dengan baik (a), selanjutnya dilakukan juga pengukuran tegangan listrik pada baterai (b), lalu dilakukan pengujian kinerja dari hidrolik elektrik, apakah sudah sesuai dengan waktu yang telah diatur pada program Arduino (c), dan yang terakhir yaitu melakukan pengujian kinerja alat secara keseluruhan dalam menarik sampah yang ada di laut (d). Kinerja alat secara keseluruhan sangat baik karena dapat menyedot sampah, walaupun tidak terlalu banyak, dengan memanfaatkan energi yang berasal dari panel surya, dan panel surya bekerja dengan baik menyerap energi matahari.

\subsection{Pengklasifikasian Jenis Sampah}

Berdasarkan jenis material sampah laut dapat dikategorikan dalam beberapa kelas [5], seperti yang ditampilkan pada Tabel 2 di bawah ini:

\begin{tabular}{|c|c|}
\multicolumn{2}{c}{} \\
\hline No & Tabel 2. Jenis-jenis sampah laut \\
\hline 1 & Plastik \\
\hline 2 & Logam/Metal \\
\hline 3 & Kaca \\
\hline 4 & Karet \\
\hline 5 & Organik \\
\hline 6 & Lain-lain \\
\hline
\end{tabular}

Sedangkan berdasarkan ukuran, sampah laut dapat dibagi menjadi beberapa jenis [6], seperti yang dapat dilihat pada Tabel 3 di bawah ini:

Tabel 3. Karekteristik sampah laut berdasarkan ukuran

\begin{tabular}{|c|c|c|}
\hline No & Jenis & Skala \\
\hline 1 & Mega & $>1 \mathrm{~m}$ \\
\hline 2 & Makro & $>2.5 \mathrm{~cm}-1 \mathrm{~m}$ \\
\hline 3 & Meso & $>5 \mathrm{~mm}-2.5 \mathrm{~cm}$ \\
\hline 4 & Mikro & $1 \mu \mathrm{m}-5 \mathrm{~mm}$ \\
\hline 5 & Nano & $<1 \mu \mathrm{m}$ \\
\hline
\end{tabular}




\section{Hasil dan Pembahasan}

\subsection{Hasil Pengujian}

Pengujian alat dilakukan pada hari jum'at tanggal 10 Agustus 2018, dilaut sengkuang. Hasil pengujian yang dilakukan yaitu untuk melihat karakteristik tegangan terhadap waktu, dan karakteristik daya dan waktu secara statis. Hasil pengujian ini dapat dilihat pada Gambar 5 dan 6.

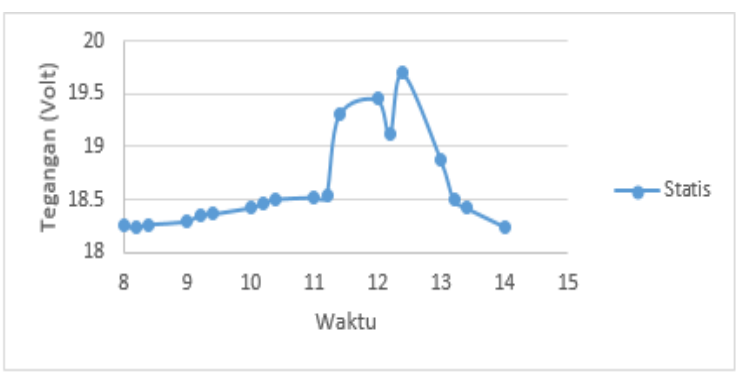

Gambar 5. Karakteristik tegangan (volt) terhadap waktu

Pada hasil uji karakteristik tegangan (volt) terhadap waktu (Gambar 5), diperoleh hasil nilai tegangan (Volt) tertinggi yaitu pada pukul 12.40 WIB dengan nilai tegangan yaitu 19,70 volt, dan tegangan (volt) terendah yaitu berada pada pukul 08.20 WIB, dengan nilai tegangan yaitu 18,23 volt. Hasil uji karakteristik daya dan waktu pada penelitian alat PSP dapat dilihat pada Gambar 6.

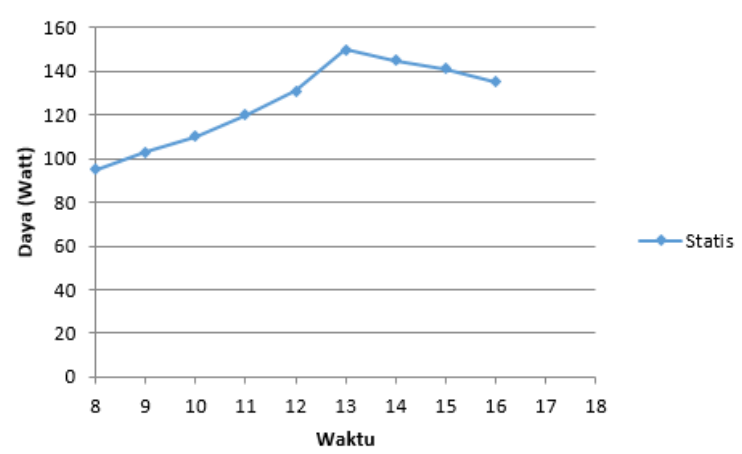

Gambar 6. Karakteristik daya (watt) dan waktu

Pada hasil uji karakteristik daya (watt) terhadap waktu (Gambar 6), diperoleh hasil nilai daya (watt) tertinggi yaitu pada pukul 13.00 WIB, dengan nilai daya yaitu 150 watt, dan daya (watt) terendah yaitu berada pada pukul $08.00 \mathrm{WIB}$, dengan nilai daya yaitu 95 watt. Hal ini memiliki perbedaan uji antara karakteristik tegangan (volt) terhadap waktu, dengan hasil uji karakteristik daya (watt) terhadap waktu pada lat PSP, perbedaan ditunjukkan dengan nilai tertinggi tidak berada pada waktu yang sama. Perolehan data
Arus laut dalam penelitian ini dapat dilihat pada Gambar 7

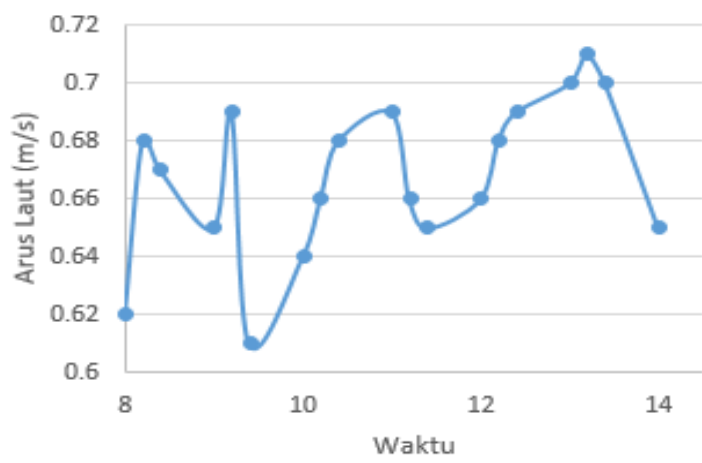

Gambar 7. Nilai kuat arus laut terhadap waktu

Pada hasil pengukuran nilai kuat arus laut terhadap waktu (Gambar 7), memiliki nilai terendah dalam kuatan arus laut yaitu berada pada pukul 09.40 dengan nilai $0.61 \mathrm{~m} / \mathrm{s}$, dan nilai kuat arus tertinggi yaitu berada pada pukul $13.00 \mathrm{WIB}$, dan $13.40 \mathrm{WIB}$ dengan nilai kuat arus laut yaitu $0.70 \mathrm{~m} / \mathrm{s}$. Hubungan anatara daya sedot pompa dengan arus laut dapat dilihat pada Gambar 8

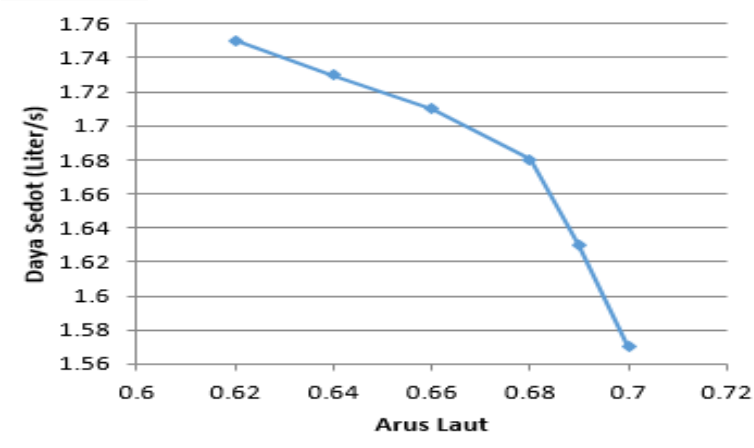

Gambar 8. Daya sedot pompa terhadap arus laut

Hubungan antara daya sedot pompa dengan arus laut (Gambar 8), daya sedot akan meningkat dengan nilai 1.75 liter/sekon saat nilai terendah dalam kuatan arus laut yaitu dengan nilai $0.61 \mathrm{~m} / \mathrm{s}$, dan daya sedot akan menurun dengan nilai 1.57 liter/sekon saat nilai kuat arus tertinggi yaitu dengan nilai yaitu $0.70 \mathrm{~m} / \mathrm{s}$.

Tabel 4. Hasil Klasifikasi Sampah yang Diperoleh

\begin{tabular}{|c|c|c|}
\hline Jenis & Ukuran & Klasifikasi \\
\hline Kantong plastik & $15-20 \mathrm{~cm}$ & Makro \\
\hline Botol minuman & $14-31 \mathrm{~cm}$ & Makro \\
\hline Dedaunan & $1-2.5 \mathrm{~cm}$ & Meso \\
\hline
\end{tabular}




\begin{tabular}{|c|c|c|}
\hline Styrofoam & $13-21$ & Makro \\
\hline Puntung rokok & $1-2 \mathrm{~cm}$ & Meso \\
\hline $\begin{array}{c}\text { Kaleng } \\
\text { minuman }\end{array}$ & $4.5-6 \mathrm{~cm}$ & Makro \\
\hline
\end{tabular}

Pada pengujian yang telah dilakukan, dihasil yang diperoleh mengenai klasifikasi jenis sampah dapat dilihat pada Tabel 4. Berdasarkan jenis material yang tertampung adalah plastik (kantong dan botol minuman); organik (dedaunan); lain-lain (styrofoam, puntung rokok, kaleng minuman). Berat maksimum sampah yang dapat tertampung adalah $1 \mathrm{~kg}$.

\section{Kesimpulan}

Perancangan alat pengumpul sampah portable (PSP) dirancang untuk mengurangi adanya sampah di pesisir laut dengan menggunakan pelantar, dan meningkatkan efektifitas dalam penerimaan energi. Berdasarkan hasil perancangan dan percobaan dapat disimpulkan bahwa kinerja alat berfungsi dengan baik, daya aktual yang dihasilkan oleh penjejak surya mencapai 600 watt. Untuk merubah tegangan 12 volt DC dari baterai menjadi tegangan 220 volt AC dengan menggunakan rangkaian inverter. Dengan demikian perancangan alat penampung sampah menggunakan panel surya dengan sistem Arduino dapat diterapkan oleh masyarakat di pesisir Batam, Kepulauan Riau.

\section{Referensi}

[1] CSIRO (Ocean and Atmosphere Flaship) 2014. Marine Debris sources, distribution and fate of plastic and other refuse - and its impact on ocean and coastal wildlife. www.csiro.au/marine-debris diakses pada pukul 17.06 WIB, tanggal 9 Agustus 2018.

[2] Ryan, P. G., Moore, C. J., van Franeker, J. A., \& Moloney, C. L. (2009). Monitoring the abundance of plastic debris in the marine environment. Philosophical Transactions of the Royal Society of London B: Biological Sciences, 364(1526), 1999-2012.

[3] Simatupang, S., Susilo, B., \& Hermanto, M. B. (2012). Rancang Bangun dan Uji Coba Solar Tracker pada Panel Surya Berbasis
Mikrokontroler ATMega16. Jurnal Keteknikan Pertanian Tropis dan Biosistem, 1(1), 55-59.

[4] Tudorache, T., \& Kreindler, L. (2010). Design of a solar tracker system for PV power plants. Acta Polytechnica Hungarica, 7(1), 23-39.

[5] Cheshire A., and Adler E., (2009). UNEP/IOC Guidelines on Survey and Monitoring of Marine Litter. United Nations Environment Program. UNEP. Intergovernmental Oceanographic Commission, IOC.

[6] Lippiat, S., Opfer, S. and Arthur, C. (2013). Marine Debris and Monitoring Assesment. NOAA, 2-5. 